\title{
Disability, economic and work-role status of individuals and their families in Bangladesh, post-unilateral lower-limb amputation (LLA) and pre-rehabilitation: a cross-sectional study
}

Md Shapin Ibne Sayeed ( $\square$ m.sayeed@latrobe.edu.au )

La Trobe University

Jodi Oakman

La Trobe University

Michael P. Dillon

La Trobe University

Rwth Stuckey

La Trobe University

\section{Research Article}

Keywords: amputation, disability, socioeconomic factors, occupational status, Bangladesh

Posted Date: May 14th, 2021

DOI: https://doi.org/10.21203/rs.3.rs-489964/v1

License: (1) This work is licensed under a Creative Commons Attribution 4.0 International License. Read Full License 


\section{Abstract \\ Background}

To quantify disability, occupation and socioeconomic status of individuals and their families in Bangladesh, post-unilateral lowerlimb amputation (LLA) and pre-rehabilitation.

\section{Methods}

Between November 2017 and February 2018, people with unilateral LLA attending two XXX prosthetic rehabilitation centres were surveyed prior to rehabilitation, using the World Health Organization Disability Assessment Schedule (WHODAS-2.0) with additional socio-economic questions. Data was analysed descriptively, and cross-tabulation conducted with Chi-square test and Fisher's exact tests.

\section{Results}

Seventy-six individuals participated. The majority had transtibial amputation (61.8\%) from trauma (64.5\%), were young adults (37.92 \pm 12.35 years), in paid work prior to LLA $(80 \%)$, married $(63.2 \%)$, male $(81.6 \%)$, from rural areas $(78.9 \%)$, with primary/no education (72.4\%). After LLA, mobility (WHODAS score $74.61 \pm 13.19)$ was the most negatively affected domain. Most $(60.5 \%)$ participants did not return to a paid or unpaid occupation. Acute healthcare costs negatively impacted most families (89.5\%), and over $80 \%$ became impoverished. Nearly $70 \%$ of previous income-earners became economically dependent resulting in changes to traditional family roles.

\section{Conclusions}

Following LLA, most participants experienced significant mobility impairment, were unable to return to paid occupation and became economically dependent. The study population presents with many different characteristics from other people with LLA globally, which suggest with timely rehabilitation a return to paid employment is possible. The impact of LLA extends beyond the individual, including to families, many of whom face challenges with changes to traditional primary earner gendered roles. Improved access to timely and affordable rehabilitation is required to reduce the significant personal and societal costs of disability after LLA.

\section{Background}

In Bangladesh the incidence of lower limb amputation (LLA) is estimated to be 75 per 100,000 population [1]; more than double the global trend estimate of 5.8-31 per 100,000 [2]. Specifically for traumatic amputation, prevalence in East Asia (11.2 million) was the highest in the world [3]. The major cause of LLA in Bangladesh is trauma (i.e., road traffic or workplace accidents) which disproportionately affects young men in rural areas [4]. Most of these men have limited education limited to primary or early secondary school, and work in physically demanding labouring jobs to support themselves and their families $[4,5]$.

Previous research has shown that LLA has a significant and negative impact on a person's physical, psychological, social and economic wellbeing and that of their family [6-11]. Many people with chronic illness experience major financial strain from the point at which acute medical care commences [12]. In Bangladesh, limited social welfare or financial support systems exist to cover healthcare and living costs which often result in high levels of debt [13-15].

In Bangladesh, families are traditionally reliant on the income of a male member, who financially supports a spouse, children and an extended family $[5,16]$. When a male family member has an amputation, the risk of family poverty increases as women are rarely engaged in paid employment [17] and social welfare is limited [18]. In this patriarchal society the loss of work role for men after LLA results in families changing their traditional roles. However, the adoption of the primary earner role by women results in very low wages given the low-literacy levels and a lack of vocational training [19] frequently leading to poverty $[15,17,20]$. 
Access to timely rehabilitation can reduce the disability, economic and work-role impact of LLA [21-23]. Timely access to rehabilitation in Bangladesh is challenged by a range of factors that result in significant delays between amputation and rehabilitation that average 6.5 years (range 0.3-60 years) [4]. Barriers to rehabilitation include the limited availability of services most are located in the major cities [24] - limited referral to, or awareness of the role of, rehabilitation in work re-integration [4, 25], high service costs [26], and concerns about ongoing costs of prosthetic replacement and maintenance [27].

While previous studies have identified delays in access to rehabilitation in Bangladesh, $[4,24-27]$ the domains of the disability and economic and changes in work-role after LLA and their family have not been explored, [6-11]. Understanding the functional domains affected by LLA (e.g., mobility, participation, cognition etc.) [28], changes in work role [29], and the association with demographic, amputation, comorbidities and economic status, it is possible to help identify those most at risk of economic hardship as well as help develop priorities for rehabilitation in Bangladesh and other countries with similarly limited resources.

\section{Methods}

A cross sectional survey was completed by people after unilateral LLA and before commencement of their first rehabilitation at two divisional prosthetic rehabilitation centres of XXX, Bangladesh. The aim of the study was to quantify disability, occupation and socioeconomic status of individuals and their families in Bangladesh, post-unilateral lower-limb amputation (LLA) and prerehabilitation.

\section{Data collection}

Data were collected between 1st November 2017 and 28th February 2018. A convenience sample of individuals attending for their first rehabilitation admission. Prospective participants were approached in the waiting room by the research assistant (RA) to enquire about their interest and assess eligibility for study inclusion.

Eligibility criteria included: being eighteen years or over, having a unilateral LLA, not having previously participated in rehabilitation, and able to voluntarily consent to participate and answer questions in Bengali. Ethics approval was received from Human Ethics Committee of La Trobe University, Melbourne, Australia (Human Research Ethics Committee No. HEC19297) and Ethics Committee Centre for the rehabilitation of the Paralysed, Bangladesh (CRP-R\&E-0401-222(2)) to conduct the research at their prosthetic rehabilitation centre

Participants were surveyed using the validated 36-item interviewer-administered questionnaire Bangla version of the World Health Organization Disability Assessment Schedule (WHODAS)-2.0 [30, 31]. The WHODAS 2.0 tool identifies rehabilitation needs, matches treatments and interventions, measures outcomes and effectiveness, sets priorities, and allocates resources [30, 31]. Additional demographic, economic and health related questions were also included. (Available from corresponding author on request)

Following consent, the survey was administered by the RA's in a private room at the Centre. WHODAS survey responses were checked for completeness and completed by the RA. Clinical and demographic data were re-checked for completeness against the centre's medical records.

\section{Data analysis}

Following screening, data were entered into SPSS 25.0 (IBM Corp. @), New York) for analysis. Using the validated process prescribed by the WHODAS [28] a "total disability score" and "individual domain score" in six domains ('cognition', 'mobility', 'self-care', 'getting along', 'participation', and 'life activities' involving household work and professional/educational activities) were calculated in 0-100 scale where, 0 indicates no disability and 100 indicates extreme disability. A categorical level of disability for individual domain scores $(0=$ No disability to $4=$ Extreme disability) were also calculated [28].

Work-role and economic data were calculated from the survey responses: occupational status change after LLA (Yes/ No); economic difficulties managing acute care of LLA (Yes/ No); and change of financial role within the family after LLA (Yes/No)..

The poverty line data calculation base used the statistical report of Bangladesh statistics 2017, at US\$1.9/day [32] equivalent to 161.06 BDT/ day (US\$ $1=84.77$ BDT) [33] and then calculated 4836 BDT (US\$57) in a month. 
Given the relatively small sample and the number of different strata, some data were recoded into binominal group for descriptive analysis. The hip disarticulation, transfemoral and knee disarticulation were recategorized into a single group called 'amputations above-the-knee'. Age was recoded from continuous to categorical data results in dichotomous groups: <40 years (young to middleaged) and $\geq 40$ years (middle to older-aged) [29]. Based on the WHODAS total disability score, participants were dichotomised into either the 'no and mild disability' or 'moderate and extreme disability' groups. Educational years were grouped to understand the effect of education, as, no/ primary education ( $0-6$ years) and secondary/ higher level education ( $6+$ years). Marital status categories were dichotomised as married or single (never married/ separated/ divorced/widowed) to identify if having a partner impacts economic outcome. Cause of LLA were categorised as traumatic (road traffic accident/ other trauma) and non-traumatic (gangrene/ infection/ tumour/ vascular/ other) to identify if a primary/ acute LLA trauma experience compared to secondary/ illness or gradual onset of LLA impact outcome. Comorbidities categories were dichotomised into with or without comorbidity: with comorbidity included one or more of the following: diabetes mellitus/ hypertension/ heart disease/ bronchial asthma no illness/ diabetes mellitus/ hypertension/ heart disease/ bronchial asthma. The without comorbidity category included participants without any of these comorbid conditions. Participants economic variables were dichotomised based on economic factors, e.g. occupation categories paid (paid worker/ self-employed/ business) and non-paid (non-paid worker/ student/ household work/ unemployed) occupations. To evaluate whether the participants were experiencing poverty after LLA or not, monthly income was dichotomised as above or below the poverty line of Bangladesh. Participant's financial role within the family was dichotomised to 'earner' (combining the two sub-categories of 'primary-earner' and 'contributor'), or 'dependent', to better identify the economic impacts on roles. Similarly, 'occupation' was also dichotomised to 'occupation with income' or 'occupation without income' (e.g. home duties), to identify the economic impact on occupational identity.

Percentages and frequency were calculated for all variables. Bivariate analysis or cross-tabulation of variables with chi- square test for associations (2x2) was undertaken to explore associations [34] given the categorical data and independence of observations. Where the minimum cell count was less than five, the Fisher's Exact Test p-value was reported.

\section{Results}

Seventy-six people with LLA from 22 districts of Bangladesh met the study inclusion criteria.

Most participants were: men, young-to-middle age, married, lived in rural areas, with little or no primary education (Table 1). Twothirds reported no comorbidities (Table 1). Amputation affected the majority of participants, being transtibial level caused by mostly trauma. LLA resulted in significant level of mobility disability, economic challenges and work-role changes post-LLA and prerehabilitation (see Figure 1).

\section{Disability levels of individuals with LLA prior to commencing rehabilitation}

The mean total WHODAS 2.0 disability score was $37.35 \pm 8.38$ (Figure 2). Of the individual domains 'cognitive function' was least impacted. 'Mobility' was the domain with the greatest disability. Categorical descriptor of "mild levels" of disability were reported for domains of 'self-care' and 'getting along'. Females reported higher levels of disability across almost all domains compared to males except for the domain of 'cognition'.

\section{Impact on family economy of managing acute care costs of LLA}

Almost $90 \%$ of participants reported that the clinical costs of acute care for LLA resulted in economic difficulties for their family (Table 2). A number of factors were associated with economic difficulties of acute care cost on the family including: age at time of interview, $(\mathrm{c} 2(1)=7.24, \mathrm{p}=0.007)$, marital status $(\mathrm{c} 2(1)=9.86, \mathrm{p}=0.003)$, financial role within family $(\mathrm{c} 2(1)=28.39, \mathrm{p}<0.001)$, occupational status $(c 2(1)=25.92, p<0.001)$, cause of amputation $(c 2(1)=4.93, p=0.045)$ and education, $(c 2(1)=10.03, p=0.005)$ (Table 3).

\section{Impact of LLA on individual's occupational status}

All participants were involved in paid ( $80 \%$ ) or unpaid (20\%) occupational roles prior to LLA (Table 2). Following LLA, around $60 \%$ of participants did not return to any form of paid or unpaid occupation. Among the participants who returned to occupation, $28 \%$ returned to their pre-LLA occupation and $12 \%$ changed to other occupation (Table 2). 
Participants who were paid employees pre-LLA were the most impacted with $78 \%$ of this group not returning to any occupation postLLA, paid or unpaid (Table 2). The other paid occupational group (self-employed/ own business) comprised $32.9 \%(n=25)$ of all participants pre-LLA, and only 8 of these participants resumed their work.

Table 3 describes a Chi-square test for association between different socio-economic, health, amputation variables with outcome variables. Change of occupational status after LLA were associated with age at the time of interview $(c 2(1)=5.14, p=0.023)$, and financial role within the family $(\mathrm{c} 2(1)=28.95, \mathrm{p}<0.001)$ and occupational status prior to the $L L A(\mathrm{c} 2(1)=32.57, \mathrm{p}<0.001)($ Table 3$)$.

\section{Change to monthly income after LLA}

Before LLA, $98 \%$ of participants reported monthly earnings above the official poverty line of Bangladesh [32] with an income range of 1,000-20,000 BDT (US\$11.8-236.04) per month. By comparison, following LLA, only $15 \%$ of participants retained an income above the poverty line (See Figure 1 and Table 2).

After LLA, participants monthly income was on average $966.67 \pm 2314.06$ BDT (US\$11.41 \pm 27.31 ) [33] and a range of 0-10,000 BDT (US\$ 0-118.03). Most of the participants (80\%) lost their entire income and 10\% reported a partial loss. Only 2 participants reported no income reduction after LLA. (Table 2 and Figure 1).

The study found no socio-economic, health, amputation variables to be associated with reduced income below the poverty line of Bangladesh following LLA and pre-rehabilitation (Table 3).

\section{Change to financial role within the family}

Prior to LLA, $80 \%$ of participants were categorised as either a primary or secondary earner within their families. Of those who were primary earners prior to LLA (69\%) $55 \%$ became dependents and only $7 \%$ maintained this status and another $7 \%$ became secondary earners within their families. (Table 2 and Figure 1). None of the secondary earners remained in their pre-LLA financial role, all became dependent on their family for support.

Change offinancial role within the family was associated with participant's: age $(c 2(1)=5.53, p=0.019)$, marital status $(c 2(1)=4.53$, $\mathrm{p}=0.033)$, pre-LLA economic role within the family $(\mathrm{c} 2(1)=37.18, \mathrm{p}<0.001)$, occupational status $(\mathrm{c} 2(1)=32.99, \mathrm{p}<0.001)$, and WHODAS score $(\mathrm{c} 2(1)=5.67, \mathrm{p}=0.029)$ (Table 3$)$.

\section{Discussion}

This study aimed to quantify disability, occupation and socioeconomic status of individuals and their families in Bangladesh, postunilateral lower-limb amputation (LLA) and pre-rehabilitation. The results of this study highlight significant levels of disability, challenges to returning to pre-LLA work roles and associated negative impacts on the economic status.

The unique characteristics of the individuals participating in the current study is in contrast to the global LLA population i.e. affecting mostly older aged with multiple other health conditions and associated with diabetes, vascular disease [2, 35] support the potential for better outcomes following rehabilitation. This study participants were young, with fewer comorbidities, no cognitive impairments or complex disability compared to those with spinal cord injury or stroke [36] and a LLA is usually associated with better rehabilitation outcomes than more proximal amputations [37].

A key finding was the significant level of mobility disability with several likely explanations. Given that participants in this study were yet to receive prosthetic rehabilitation there were likely greater difficulties including [38]. Public access for people with physical disabilities in Bangladesh is limited by the absence of sealed footpaths, uneven or muddy roads, poor drainage systems, inaccessible foot bridges, road access blocked by illegal occupants [39, 40] and an absence of accessible public transportation [40]. The resulting disability had a significant impact on personal and domestic activities, community access and work participation [18, 36].

Most people with a LLA - and by extension their families - become impoverished (below the Bangladesh poverty line) creating a risk for multigenerational poverty and downgrading of socioeconomic class [41]. This change in social status is often associated with shame and embarrassment which is compounded by their ongoing need for personal care and feeling like a burden to their family 
[42]. In Bangladesh, a lack of financial support for healthcare means challenges arise in paying for acute care cost which impacts the whole family [13]. The impact of acute care-related financial hardship creates a barrier to rehabilitation access which is not experienced by those with LLA in many other settings and has not been previously researched. Individuals often leave acute care after LLA without referral to or awareness of rehabilitation [4] and live with multiple physical, psychological, social [43] and economic challenges [38] limiting opportunities for undertaking work [44] thus resulting in very significant financial difficulties.

A significant proportion of participants had not returned to their pre-LLA occupation, or any occupation. This significant reduction in occupational participation is likely to reflect the physically demanding nature of the work undertaken by people with lower socioeconomic and educational characteristics (e.g., many people are in labouring-type jobs) combined with factors like environmental challenges [5]. The absence of financial support and vocational retraining impacts all family members [45] requiring significant changes to traditional financial roles.

Changes of traditional financial roles within families post-LLA are culturally challenging $[17,42]$. Given that males are almost always the primary income earner, their disability affects the whole family. Women taking on the role of a primary-earner role often impacts children, particularly girls, who commonly leave school to provide full-time family care, contributing to the generational impact of disability, illiteracy and poverty [46-48]. For women with an LLA, the impact of a physical disability is complicated by cultural expectations that they continue to undertake home duties. However, without appropriate rehabilitation and home modifications, their capacity to undertake domestic roles is extremely limited [5]. Some children leave education to support on their mother's domestic duties or, children are required to take on paid employment to support basic needs of the family [48].

\section{Future research}

Further exploration is required to understand the barriers to accessing rehabilitation and the factors contributing to disability prior to rehabilitation. Research is also needed to investigate the cost impacts of acute care and barriers to referral for timely rehabilitation after acute care. Research from the perspectives of people with LLA, rehabilitation clinicians, along with potential and current employers is also needed to inform the development of comprehensive programs to facilitate improved outcomes for individuals with LLA.

\section{Strength and Limitations}

There are a number of strength and limitations to this work that require discussion to help contextualise the results. While the sample size was limited as only one or two eligible people post-LLA presented for rehabilitation each day at the centres where data collection took place. Given the short window of data collection, the sample size was relatively small which limits the available statistical methods for analysis but for a study of association it is adequate. Some readers may be concerned that the method of convenience sampling biased the sample generalisability [49] because those who were unable to attend the centre were not represented in the sample. We can have some confidence in the representativeness of the sample given the cohort were similar to other larger studies [1, 4] of the Bangladeshi LLA population. However, the demographics of participants in this study are similar to those of participants in other studies [1,4] which include people with LLAs in Bangladesh, suggesting this is not a significant concern. The number of people in other strata (e.g., transfemoral amputation) were limited but this also reflects the global LLA population characteristics [2]. Most components of the survey used validated and reliable tool (WHODAS) but some economic components were self-reported (income, acute care cost, financial status) which may limit reliability. Regardless this this is the first collection of data of this kind in Bangladesh and provides valuable insight into life after LLA before rehabilitation.

\section{Conclusion}

In Bangladesh, most people experienced mobility impairment and disability in the period between LLA and prosthetic rehabilitation. During this period, most did not return to any occupation with subsequent loss of income resulting in economic hardship. Given the most people with LLA are relatively young population with few comorbidities, they would likely benefit from early access to rehabilitation. Improved access to timely and affordable rehabilitation is required to reduce the significant personal, family and societal costs of disability due to LLA. Findings from this study have potential implications for those with LLA in other low-income countries. 


\section{Abbreviations}

BDT: Bangladeshi Taka

LLA: Lower Limb Amputation

RA: Research Assistant

SPSS: Statistical Package for the Social Sciences

US\$: United States Doller

WHODAS: World Health Organization Desirability Assessment Schedule

\section{Declarations}

Ethics approval and Consent to participate: Ethical approval has been received from Human Ethics Committee of La Trobe University, Melbourne, Australia and Ethics Committee Centre for the rehabilitation of the Paralysed, Bangladesh to conduct the research at their prosthetic rehabilitation centre. All procedures followed were in accordance with the ethical standards of the responsible committee on human experimentation (institutional and national) and with the Helsinki Declaration of 1975, as revised in 2000. Consent to participate has been received from the participant as required by the ethics approval body. Informed consent was obtained from all patients for being included in the study.

Consent to Publish: Not applicable

Availability of data and material: The datasets used and/or analysed during the current study available from the corresponding author on reasonable request.

Conflicts of interests: All the authors report no conflicts of interest.

Funding: The author $\mathrm{W}$, author $\mathrm{X}$, author $\mathrm{Y}$ and author $\mathrm{Z}$ declare that they have not received any funding for the study.

Authors' contributions: All the authors contributed to the study.

Acknowledgment: Sincere thanks to the people with LLA who participated in this study, and WW, XX, and YY for their assistance with data collection, and ZZ for assistance with initial data analysis of the WHODAS scales.

\section{References}

1. Aftabuddin M, Islam N, Jafar MAHMJ, Haque I. The status of lower-limb amputation in Bangladesh: A 6-year review. Surg Today. 1997;27:130-4. doi:https://doi.org/10.1007/BF02385901.

2. Moxey PW, Gogalniceanu P, Hinchliffe RJ, Loftus IM, Jones KJ, Thompson MM, et al. Lower extremity amputations - a review of global variability in incidence. Diabet Med. 2011;28:1144-53. doi:10.1111/j.1464-5491.2011.03279.x.

3. McDonald CL, Westcott-McCoy S, Weaver MR, Haagsma J, Kartin D. Global prevalence of traumatic non-fatal limb amputation. Prosthet Orthot Int. 2020;:1-12.

4. Hassan Al Imam M, Alamgir H, Jahan Akhtar N, Hossain Z, Islam R, Sohrab Hossain M, et al. Characterisation of persons with lower limb amputation who attended a tertiary rehabilitation centre in Bangladesh. Disabil Rehabil. 2019;0:1-7. doi:10.1080/09638288.2018.1544671.

5. Stuckey R, Draganovic P, Ullah MM, Fossey E, Dillon MP. Barriers and facilitators to work participation for persons with lower limb amputations in Bangladesh following prosthetic rehabilitation. Prosthet Orthot Int. 2020;44:279-89. doi:10.1177/0309364620934322.

6. Ali S, Fatima Haider SK. Psychological Adjustment To Amputation: Variations On The Bases Of Sex, Age And Cause Of Limb Loss. J Ayub Med Coll Abbottabad. 2017;29:303-7.

https://jamc.ayubmed.edu.pk/jamc/index.php/jamc/article/view/2130/974.

Page $7 / 14$ 
7. Aliya Hisam, Fatimah Ashraf, Mariam Nadeem Rana, Yumna Waqar SK and Fl. Health Related Quality of Life in Patients with Single Lower Limb Amputation. Dep Community Med Army Med Coll Natl Univ Med Sci (NUMS), Rawalpindi. 2016;26 (10) October:851-4. https://www.researchgate.net/publication/310750995.

8. Schoppen T, Boonstra A, Groothoff JW, Sonderen E van, Göeken LN, Eisma WH. Factors related to successful job reintegration of people with a lower limb amputation. Arch Phys Med Rehabil. 2001;82:1425-31. doi:10.1053/APMR.2001.26074.

9. Sinha R, van den Heuvel WJAA, Arokiasamy P, Wan Den Heuvel WJ, Arokiasamy P, van den Heuvel WJAA, et al. Factors affecting quality of life in lower limb amputees. Prosthet Orthot Int. 2011;35:90-6. doi:10.1177/0309364610397087.

10. Heszlein-Lossius HE, Al-Borno Y, Shaqqoura S, Skaik N, Giil LM, Gilbert M. Does pain, psychological distress and deteriorated family economy follow traumatic amputation among war casualties? A retrospective, cross-sectional study from Gaza. BMJ Open. 2019;9. doi:10.1136/bmjopen-2019-029892.

11. Journeay WS, Pauley T, Kowgier M, Devlin M. Return to work after occupational and non-occupational lower extremity amputation. Occup Med (Chic III). 2018;68:438-43. doi:10.1093/occmed/kqy091.

12. Alfonso NY, Alonge O, Hoque DME, Baset KU, Hyder AA, Bishai D. Care-seeking patterns and direct economic burden of injuries in Bangladesh. Int J Environ Res Public Health. 2017;14:1-9. doi:10.3390/ijerph14050472.

13. Hamid SA, Ahsan SM, Begum A. Disease-Specific Impoverishment Impact of Out-of-Pocket Payments for Health Care: Evidence from Rural Bangladesh. Appl Health Econ Health Policy. 2014;12:421-33. doi:10.1007/s40258-014-0100-2.

14. Molla AA, Chi C. Who pays for healthcare in Bangladesh? An analysis of progressivity in health systems financing. Int $J$ Equity Health. 2017;16. doi:10.1186/s12939-017-0654-3.

15. Kabir A, Datta R, Raza SH, Maitrot MRL. Health shocks, care-seeking behaviour and coping strategies of extreme poor households in Bangladesh's Chittagong Hill tracts. BMC Public Health. 2019;19:1-12. doi:10.1186/s12889-019-7335-7.

16. Rahman F, Chowdhury M, Kabir H, Alam J, Uddin J, Evans A. Outcome of Clubfoot Correction at 'Walk for Life' Clinic of Mymensingh Medical College Hospital: A Four Year Review. Bangladesh Med Res Counc Bull. 2019;44:132-7. doi:10.3329/bmrcb.v44i3.39936.

17. Selin H. Parenting Across Cultures_ Childrearing, Motherhood and Fatherhood in Non-Western Cultures. Heidelberg: Springer, Dordrecht; 2014. doi:10.1007/978-94-007-7503-9.

18. Sultana Z. Agony of Persons with Disability- A Comparative Study of Bangladesh. J Polit Law. 2010;3:212-21. https://heinonline.org/HOL/P?h=hein.journals/jpola3\&i=348.

19. Rolland JS. Parental illness and disability: a family systems framework. J Fam Ther. 1999;21:242-66. doi:10.1111/14676427.00118 .

20. Pryer J. The impact of adult ill-health on household income and nutrition in Khulna, Bangladesh. Environ Urban. 1993;5:35-49. doi:10.1177/095624789300500204.

21. Sirois M-J, Lavoie A, Dionne CE. Impact of Transfer Delays to Rehabilitation in Patients With Severe Trauma. Arch Phys Med Rehabil. 2004;85:184-91. doi:10.1016/j.apmr.2003.06.009.

22. Savafi S, Akkufi S, Soyupek FC, Ilgün E, Yildiz S. Impact of Delayed Initiation to Stroke Rehabilitation on Functional Outcomes and Medical Complications. Turk J Phys Med Rehab. 2007;53:45-9. https://www.archives-pmr.org/article/S00039993(03)00937-7/pdf. Accessed 27 Nov 2019.

23. Naschitz JEE, Lenger R. Why traumatic leg amputees are at increased risk for cardiovascular diseases. Qjm. 2008;101:251-9. doi:10.1093/qjmed/hcm131.

24. Cochrane H, Rosario D, Singh A, Ghosh R. Prosthetics and Orththotics Impact Assessment India and Bangladesh. 2015; June:140. https://cdn.ymaws.com/www.ispoint.org/resource/resmgr/4_EXCHANGE/india_bangladesh_ispo_impact.pdf. Accessed 2 Apr 2019.

25. Kam S, Kent M, Khodaverdian A, Daiter L, Njelesani J, Cameron D, et al. The influence of environmental and personal factors on participation of lower-limb prosthetic users in low-income countries: prosthetists' perspectives. Disabil Rehabil Assist Technol. 2015;10 3 PG-245-51:245-51. doi:10.3109/17483107.2014.905643.

26. Mamin FA, Hayes R. Physiotherapy in Bangladesh: Inequality Begets Inequality. Front Public Heal. 2018;6:80. doi:10.3389/fpubh.2018.00080. 
27. Verhoeff TT, Poetsma PA, Gasser L, Tung H. Evaluation of use and durability of polypropylene trans-tibial prostheses. Prosthet Orthot Int. 1999;23:249-55. doi:10.3109/03093649909071642.

28. Ustun TB, Kostansjsek N, Chatterji JR. Measuring health and disability: manual for WHO disability assessment schedule. World Health Organisation (WHO); 2010. http://www.who.int/whodas.

29. Schoppen T, Boonstra A, Groothoff JW, De Vries J, Göeken LNH, Eisma WH. Employment status, job characteristics, and workrelated health experience of people with a lower limb amputation in the Netherlands. Arch Phys Med Rehabil. 2001;82:239-45. doi:10.1053/apmr.2001.18231.

30. Üstün TB, Chatterji S, Kostanjsek N, Rehm J, Kennedy C, Epping-Jordan J, et al. Developing the world health organization disability assessment schedule 2.0. Bull World Health Organ. 2010;88:815-23. doi:10.2471/BLT.09.067231.

31. World Health Organisation (WHO). Whodas 2.0 (Bangla Version). WHODAS 2.0. 2018;2.0:4-7. https://apps.who.int/iris/bitstream/handle/10665/43974/9789241547598_ben.pdf?sequence=20\&isAllowed=y.

32. Bangladesh Bureau of Statistics. Bangladesh Statistics Report 2017. 2017;:66. http://bbs.portal.gov.bd/sites/default/files/files/bbs.portal.gov.bd/page/a1d32f13_8553_44f1_92e6_8ff80a4ff82e/Bangladesh Statistics-2017.pdf.

33. XE.com Inc. XE: Convert BDT/USD. Bangladesh Taka to United States Dollar. 2020. https://www.xe.com/currencyconverter/convert/?Amount=1\&From=BDT\&To=USD. Accessed 17 Jan 2020.

34. Luck S. Factoring a $2 \times 2$ contingency table. PLoS One. 2019;14:1-23. doi:10.1371/journal.pone.0224460.

35. Godlwana L, Nadasan T, Puckree T. Global Trends in Incidence of Lower Limb Amputation: SA J Physiother. 2008;64:1-5. http://www.sajp.co.za/index.php/sajp/article/viewFile/93/90.

36. Tarvonen-Schröder S, Tenovuo O, Kaljonen A, Laimi K. Comparing disability between traumatic brain injury and spinal cord injury using the 12-item WHODAS 2.0 and the WHO minimal generic data set covering functioning and health. Clin Rehabil. 2018;32:1676-83. doi:10.1177/0269215518785945.

37. Frlan-Vrgoc L, Vrbanić TS-L, Kraguljac D, Kovacević M. Functional outcome assessment of lower limb amputees and prosthetic users with a 2-minute walk test. Coll Antropol. 2011;35:1215-8. http://www.ncbi.nlm.nih.gov/pubmed/22397262.

38. Miller TA, Paul R, Forthofer M, Wurdeman SR. Impact of Time to Receipt of Prosthesis on Total Healthcare Costs 12 Months Postamputation. Am J Phys Med Rehabil. 2020;99:1026-31. doi:10.1097/PHM.0000000000001473.

39. Alam MJ, Bryant W. Access to water and sanitation for people with paraplegia living in rural communities in Bangladesh. Cogent Med. 2016;3:Online. doi:10.1080/2331205x.2016.1233686.

40. Akter KK. Accessibility for the people with physical disabilities. The Daily Star. 2017. https://www.thedailystar.net/law-ourrights/rights-advocacy/accessibility-the-people-physical-disabilities-1353433. Accessed 14 May 2020.

41. Chowdhury FD. Theorising patriarchy: The Bangladesh context. Asian J Soc Sci. 2009;37:599-622. doi:10.1163/156853109X460200.

42. Lahtinen H, Sirniö O, Martikainen P. Social class and the risk of unemployment: Trends, gender differences and the contribution of education. Acta Sociol (United Kingdom). 2020;63:303-21. doi:10.1177/0001699318817594.

43. Thakur SJ, Thakur SJ. Compensation for Work Related Injury or Illness under the Bangladesh Labour Act. IOSR J Bus Manag. 2017;19:21-6. doi:10.9790/487X-1909042126.

44. Sansam K, Neumann V, O'Connor R, Bhakta B. Predicting walking ability following lower limb amputation: A systematic review of the literature. J Rehabil Med. 2009;41:593-603. doi:10.2340/16501977-0393.

45. Brown HV, Hollis V. The Meaning of Occupation, Occupational Need, and Occupational Therapy in a Military Context. Phys Ther. 2013;93:1244-53. doi:10.2522/ptj.20120162.

46. Islam Sarker MN, Wu M, Hossin MA. Economic effect of school dropout in Bangladesh. Int J Inf Educ Technol. 2019;9:136-42. doi:10.18178/ijiet.2019.9.2.1188.

47. Ali Z. Economic Costs of Disability in Bangladesh. Dhaka; 2014. http://bids.org.bd/uploads/publication/BDS/37/374/2_Economics of Disability in Bangladesh.pdf. Accessed 27 Jun 2019.

48. Senra H, Oliveira RA, Leal I, Vieira C. Beyond the body image: A qualitative study on how adults experience lower limb amputation. Clin Rehabil. 2011;26:180-91. doi:10.1177/0269215511410731. 
49. Jager J, Putnick DL, Bornstein MH. More than Just Convenient: The Scientific Merits of Homogeneous Convenience Samples. Monogr Soc Res Child Dev. 2017;82:13-30. doi:10.1111/mono.12296.

\section{Tables}

Table 1: Participants socio-demographic, amputation and health characteristics

\begin{tabular}{|c|c|c|}
\hline & $\mathrm{N}=76$ & $\%$ \\
\hline \multicolumn{3}{|l|}{ Gender } \\
\hline Male & 62 & 81.6 \\
\hline Female & 14 & 18.4 \\
\hline Age (years - mean (SD)) & \multicolumn{2}{|c|}{$37.92(12.35)$} \\
\hline$<40$ years & 42 & 55.3 \\
\hline$\geq 40$ years & 34 & 44.7 \\
\hline \multicolumn{3}{|l|}{ Marital status } \\
\hline Married & 48 & 63.2 \\
\hline Single & 28 & 36.8 \\
\hline Never married & 24 & 31.6 \\
\hline Separated & 1 & 1.3 \\
\hline Divorced & 1 & 1.3 \\
\hline Widowed & 2 & 2.6 \\
\hline \multicolumn{3}{|l|}{ Geographical location } \\
\hline Rural & 60 & 78.9 \\
\hline Urban & 16 & 21.1 \\
\hline Education (years - mean (SD) & \multicolumn{2}{|c|}{$5.53(4.23)$} \\
\hline No or Primary & 55 & 72.4 \\
\hline Secondary or above & 21 & 27.6 \\
\hline \multicolumn{3}{|l|}{ Co-morbidities } \\
\hline No & 50 & 65.8 \\
\hline Yes & 26 & 34.2 \\
\hline Diabetic & 19 & 25.0 \\
\hline Hypertensive & 4 & 5.3 \\
\hline Heart disease & 1 & 1.3 \\
\hline Bronchial Asthmatic & 2 & 2.6 \\
\hline Other & 0 & 0.0 \\
\hline \multicolumn{3}{|l|}{ Level of amputation } \\
\hline Above knee amputation & 25 & 32.9 \\
\hline Hip Disarticulation & 1 & 1.3 \\
\hline Trans-femoral Amputation & 21 & 27.6 \\
\hline Knee disarticulation & 3 & 3.9 \\
\hline Below knee amputation & 51 & 67.1 \\
\hline Trans-tibial Amputation & 47 & 61.8 \\
\hline Ankle disarticulation & 1 & 1.3 \\
\hline Partial Foot Amputation & 3 & 3.9 \\
\hline \multicolumn{3}{|l|}{ Cause of amputation } \\
\hline Non-traumatic & 27 & 35.5 \\
\hline Infection/ Gangrene & 22 & 28.9 \\
\hline Tumour & 3 & 3.9 \\
\hline Vascular & 1 & 1.3 \\
\hline Other & 1 & 1.3 \\
\hline Traumatic- Road traffic/ other accident & 49 & 64.5 \\
\hline
\end{tabular}

Table 2: Participants socio-economic variables 


\begin{tabular}{|c|c|c|c|c|}
\hline & \multicolumn{2}{|c|}{$\begin{array}{l}\text { Pre-LLA } \\
(\mathrm{N}=76)\end{array}$} & \multicolumn{2}{|c|}{$\begin{array}{l}\text { Post-LLA- Pre- Rehabilitation } \\
(\mathrm{N}=76)\end{array}$} \\
\hline & $\mathrm{N}$ & $\%$ & $\mathrm{n}$ & $\%$ \\
\hline \multicolumn{5}{|c|}{ WHODAS measurement of the extent of disabilities } \\
\hline \multicolumn{5}{|c|}{ Working at a Lower Level - post-LLA } \\
\hline No- working at the same level & & & 7 & 9.2 \\
\hline Yes- working at a lower level & & & 69 & 90.8 \\
\hline \multicolumn{5}{|l|}{ Work in last 30 Days (mean (SD)) } \\
\hline Days totally unable to work & & & $4.66(3.75)$ & \\
\hline Days reduced work & & & $15.4(6.60)$ & \\
\hline \multicolumn{5}{|l|}{ Occupational Status } \\
\hline Paid Occupations & 61 & 80.3 & 11 & 14.5 \\
\hline Paid Worker & 36 & 47.4 & 3 & 3.9 \\
\hline Self-employed/ Business & 25 & 32.9 & 8 & 10.5 \\
\hline Non-paid Occupations/ Unemployed & 15 & 19.7 & 65 & 85.5 \\
\hline Non-paid worker & 1 & 1.3 & 2 & 2.6 \\
\hline Student & 9 & 11.8 & 7 & 9.2 \\
\hline Household work & 5 & 6.6 & 10 & 13.2 \\
\hline Unemployed & 0 & 0 & 46 & 60.5 \\
\hline \multicolumn{5}{|l|}{ Occupational Status Change } \\
\hline No- Returned to same occupation & & & 21 & 27.6 \\
\hline Yes & & & 55 & 72.4 \\
\hline Returned to different occupation & & & 9 & 11.8 \\
\hline Failed to return to occupation & & & 46 & 60.5 \\
\hline \multicolumn{5}{|c|}{ Economic Difficulties Managing Acute Care Cost of LLA } \\
\hline \multicolumn{5}{|c|}{ No } \\
\hline Yes & & & 8 & 10.5 \\
\hline \multicolumn{5}{|l|}{ Monthly Income* } \\
\hline Below the poverty line & 1 & 1.7 & 51 & 85.0 \\
\hline No income & 0 & 0.0 & 50 & 83.3 \\
\hline Income below poverty line & 1 & 1.7 & 1 & 1.7 \\
\hline Above the poverty line & 59 & 98.3 & 9 & 15.0 \\
\hline Monthly Income Change* & & - & & \\
\hline Total income loss (No Income) & _ & & 50 & 83.3 \\
\hline Partial/ not reduced income & & & 10 & 16.7 \\
\hline Not reduced income & & & 2 & 3.3 \\
\hline Partial reduced income & & & 8 & 13.3 \\
\hline \multicolumn{5}{|l|}{ Economic Role within the Family } \\
\hline Earner Role & 62 & 81.6 & 10 & 13.2 \\
\hline Primary Earner & 52 & 68.4 & 5 & 6.6 \\
\hline Secondary Earner & 10 & 13.2 & 5 & 6.6 \\
\hline Dependent Role & 14 & 18.4 & 66 & 86.8 \\
\hline Change of Economic Role within the Family & - & - & & \\
\hline No- remained in the same role** & & & 19 & 25.0 \\
\hline Yes- changed from their usual role & & & 57 & 75.0 \\
\hline Became secondary earner & & & 5 & 6.6 \\
\hline Became dependent & & & 52 & 68.4 \\
\hline
\end{tabular}

*excludes participants who did not disclose their monthly income $(2.6 \%, \mathrm{n}=2)$ and those who had no income before LLA $(18.9 \%, \mathrm{n}=14)$

**includes dependents $(18.9 \%, \mathrm{n}=14)$ - no changes observed pre and post LLA among this group

Table 3: Cross-tabulations of socio-economic, health, amputation variables with outcome variables 


\begin{tabular}{|c|c|c|c|c|c|c|c|c|}
\hline \multirow[t]{2}{*}{ Variable } & \multicolumn{2}{|c|}{$\begin{array}{l}\text { Occupational status } \\
\text { change after LLA } \\
(\mathrm{n}=76)\end{array}$} & \multicolumn{2}{|c|}{$\begin{array}{l}\text { Economic difficulties } \\
\text { managing acute care } \\
\text { cost of LLA }(n=76)\end{array}$} & \multicolumn{2}{|c|}{$\begin{array}{l}\text { Monthly income reduced } \\
\text { compared to the poverty } \\
\text { line after LLA }(\mathrm{n}=60) *\end{array}$} & \multicolumn{2}{|c|}{$\begin{array}{l}\text { Change of economic } \\
\text { role within the family } \\
\text { after LLA }(\mathrm{n}=76)\end{array}$} \\
\hline & $\begin{array}{l}\text { No } \\
\text { n (\%) }\end{array}$ & $\begin{array}{l}\text { Yes } \\
\text { n (\%) }\end{array}$ & $\begin{array}{l}\text { No } \\
\text { n (\%) }\end{array}$ & $\begin{array}{l}\text { Yes } \\
\text { n (\%) }\end{array}$ & $\begin{array}{l}\text { No } \\
\text { n (\%) }\end{array}$ & $\begin{array}{l}\text { Yes } \\
\text { n (\%) }\end{array}$ & $\begin{array}{l}\text { No } \\
\text { n (\%) }\end{array}$ & $\begin{array}{l}\text { Yes } \\
\text { n (\%) }\end{array}$ \\
\hline $\begin{array}{l}\text { Age (at time of } \\
\text { interview) }\end{array}$ & \multicolumn{2}{|c|}{$\begin{array}{l}c 2(1)=5.14 \\
p=0.023^{* *}\end{array}$} & \multicolumn{2}{|c|}{$\begin{array}{l}\mathrm{c} 2(1)=7.24, \mathrm{p}= \\
0.007 * * \wedge\end{array}$} & \multicolumn{2}{|c|}{$\mathrm{c} 2(1)=2.26, \mathrm{p}=0.175^{\wedge}$} & \multicolumn{2}{|c|}{$\begin{array}{l}\mathrm{c} 2(1)=5.53, \mathrm{p}= \\
0.019^{* *}\end{array}$} \\
\hline $\begin{array}{l}\text { Below } 40 \\
\text { years } \\
40 \text { years and } \\
\text { above }\end{array}$ & $\begin{array}{l}16 \\
(21.1 \%) \\
5(6.6 \%)\end{array}$ & $\begin{array}{l}26 \\
(34.2 \%) \\
29 \\
(38.2 \%)\end{array}$ & $\begin{array}{l}8 \\
(10.5 \%) \\
0(0 \%)\end{array}$ & $\begin{array}{l}34(44.7 \%) \\
34(44.7 \%)\end{array}$ & $\begin{array}{l}7(11.7 \%) \\
3(5.0 \%)\end{array}$ & $\begin{array}{l}22(36.7 \%) \\
28(46.7 \%)\end{array}$ & $\begin{array}{l}18(23.7 \%) \\
6(7.9 \%)\end{array}$ & $\begin{array}{l}24 \\
(31.6 \%) \\
28 \\
(36.8 \%)\end{array}$ \\
\hline $\begin{array}{l}\text { Sex } \\
\text { Female }\end{array}$ & \multicolumn{2}{|c|}{$\begin{array}{l}\mathrm{c} 2(1)=1.99, \mathrm{p}= \\
0.158\end{array}$} & \multicolumn{2}{|c|}{$\begin{array}{l}\mathrm{c} 2(1)=0.21, \mathrm{p}= \\
1.000^{\wedge}\end{array}$} & \multicolumn{2}{|c|}{$\mathrm{c} 2(1)=0.12, \mathrm{p}=1.000^{\wedge}$} & \multicolumn{2}{|c|}{$\mathrm{c} 2(1)=1.01, \mathrm{p}=0.315$} \\
\hline Male & $\begin{array}{l}6(7.9 \%) \\
15(19.7 \%)\end{array}$ & $\begin{array}{l}8 \\
(10.5 \%) \\
47 \\
(61.8 \%)\end{array}$ & $\begin{array}{l}1(1.3 \%) \\
7(9.2 \%)\end{array}$ & $\begin{array}{l}13(17.1 \%) \\
55(72.4 \%)\end{array}$ & $\begin{array}{l}1(1.7 \%) \\
9(15 \%)\end{array}$ & $\begin{array}{l}7(11.7 \%) \\
43(71.7 \%)\end{array}$ & $\begin{array}{l}6(7.9 \%) \\
18 \\
(23.7 \%)\end{array}$ & $\begin{array}{l}8(10.5 \%) \\
44 \\
(57.9 \%)\end{array}$ \\
\hline $\begin{array}{l}\text { Geographical } \\
\text { location }\end{array}$ & \multicolumn{2}{|c|}{$\begin{array}{l}\mathrm{c} 2(1)=2.63, \mathrm{p}= \\
0.105\end{array}$} & \multicolumn{2}{|c|}{$\begin{array}{l}\mathrm{c} 2(1)=0.08, \mathrm{p}= \\
0.672^{\wedge}\end{array}$} & \multicolumn{2}{|c|}{$\mathrm{c} 2(1)=0.75, \mathrm{p}=0.403^{\wedge}$} & \multicolumn{2}{|c|}{$\mathrm{c} 2(1)=3.18, p=0.074$} \\
\hline $\begin{array}{l}\text { Rural } \\
\text { Urban }\end{array}$ & $\begin{array}{l}14(18.4 \%) \\
7(9.2 \%)\end{array}$ & $\begin{array}{l}46 \\
(60.5 \%) \\
9 \\
(11.8 \%)\end{array}$ & $\begin{array}{l}6(7.9 \%) \\
2(2.6 \%)\end{array}$ & $\begin{array}{l}54(71.1 \%) \\
14(18.4 \%)\end{array}$ & $\begin{array}{l}7(11.7 \%) \\
3(5.0 \%)\end{array}$ & $\begin{array}{l}41(68.3 \%) \\
9(15.0 \%)\end{array}$ & $\begin{array}{l}16 \\
(21.1 \%) \\
8(10.5 \%)\end{array}$ & $\begin{array}{l}44 \\
(57.9 \%) \\
8(10.5 \%)\end{array}$ \\
\hline $\begin{array}{l}\text { Education } \\
\text { No/ Primary }\end{array}$ & \multicolumn{2}{|c|}{$\begin{array}{l}\mathrm{c} 2(1)=1.59, \mathrm{p}= \\
0.207\end{array}$} & \multicolumn{2}{|c|}{$\begin{array}{l}\mathrm{c} 2(1)=10.03, \mathrm{p}= \\
0.005^{* * \wedge}\end{array}$} & \multicolumn{2}{|c|}{$\mathrm{c} 2(1)=0.75, \mathrm{p}=0.670^{\wedge}$} & \multicolumn{2}{|c|}{$\mathrm{c} 2(1)=1.71, \mathrm{p}=0.194$} \\
\hline $\begin{array}{l}\text { Secondary/ } \\
\text { Higher }\end{array}$ & $\begin{array}{l}13(17.1 \%) \\
8(10.5 \%)\end{array}$ & $\begin{array}{l}42 \\
(55.3 \%) \\
13 \\
(17.1 \%)\end{array}$ & $\begin{array}{l}2(2.6 \%) \\
6(7.9 \%)\end{array}$ & $\begin{array}{c}53(69.7 \%) \\
15(19.7 \%)\end{array}$ & $\begin{array}{l}9(15.0 \%) \\
1(1.7 \%)\end{array}$ & $\begin{array}{l}39(65.0 \%) \\
11(18.3 \%)\end{array}$ & $\begin{array}{l}15 \\
(19.7 \%) \\
9(11.8 \%)\end{array}$ & $\begin{array}{l}40 \\
(52.6 \%) \\
12 \\
(15.8 \%)\end{array}$ \\
\hline $\begin{array}{l}\text { Marital Status } \\
\text { Married }\end{array}$ & \multicolumn{2}{|c|}{$\begin{array}{l}\mathrm{c} 2(1)=3.01, \mathrm{p}= \\
0.083\end{array}$} & \multicolumn{2}{|c|}{$\begin{array}{l}\mathrm{c} 2(1)=9.86, \mathrm{p}= \\
0.003^{* *}\end{array}$} & \multicolumn{2}{|c|}{$\mathrm{c} 2(1)=1.44, \mathrm{p}=0.426^{\wedge}$} & \multicolumn{2}{|c|}{$\begin{array}{l}\mathrm{c} 2(1)=4.53, \mathrm{p}= \\
0.033^{* *}\end{array}$} \\
\hline Single & $\begin{array}{l}10(13.2 \%) \\
11(14.5 \%)\end{array}$ & $\begin{array}{l}38 \\
(50 \%) \\
17 \\
(22.4 \%)\end{array}$ & $\begin{array}{l}1(1.3 \%) \\
7(9.2 \%)\end{array}$ & $\begin{array}{l}47(61.8 \%) \\
21(27.6 \%)\end{array}$ & $\begin{array}{l}9(15.0 \%) \\
1(1.7 \%)\end{array}$ & $\begin{array}{l}36(60.0 \%) \\
14(23.3 \%)\end{array}$ & $\begin{array}{l}11 \\
(14.5 \%) \\
13 \\
(17.1 \%)\end{array}$ & $\begin{array}{l}37 \\
(48.7 \%) \\
15 \\
(19.7 \%)\end{array}$ \\
\hline $\begin{array}{l}\text { Level of } \\
\text { Amputation }\end{array}$ & \multicolumn{2}{|c|}{$\begin{array}{l}\mathrm{c} 2(1)=0.36, \mathrm{p}= \\
0.551\end{array}$} & \multicolumn{2}{|c|}{$\begin{array}{l}\mathrm{c} 2(1)=1.69, \mathrm{p}= \\
0.259 \wedge\end{array}$} & \multicolumn{2}{|c|}{$\mathrm{c} 2(1)=3.30, \mathrm{p}=0.143^{\wedge}$} & \multicolumn{2}{|c|}{$\begin{array}{l}\mathrm{c} 2(1)=0.003, \mathrm{p}= \\
0.956\end{array}$} \\
\hline $\begin{array}{l}\text { Above Knee } \\
\text { Below Knee }\end{array}$ & $\begin{array}{l}8(10.5 \%) \\
13 \\
(17.1 \%)\end{array}$ & $\begin{array}{l}17 \\
(22.4 \%) \\
38 \\
(50 \%)\end{array}$ & $\begin{array}{l}1(1.3 \%) \\
7(9.2 \%)\end{array}$ & $\begin{array}{l}24(31.6 \%) \\
44(57.9 \%)\end{array}$ & $\begin{array}{l}6(10.0 \%) \\
4(6.7 \%)\end{array}$ & $\begin{array}{l}15(25.0 \%) \\
35(58.3 \%)\end{array}$ & $\begin{array}{l}8(10.5 \%) \\
16 \\
(21.1 \%)\end{array}$ & $\begin{array}{l}17 \\
(22.4 \%) \\
35 \\
(46.1 \%) \\
n=0.431\end{array}$ \\
\hline $\begin{array}{l}\text { Cause of } \\
\text { Amputation }\end{array}$ & \multicolumn{2}{|c|}{$\begin{array}{l}\mathrm{c} 2(1)=1.74, \mathrm{p}= \\
0.187\end{array}$} & \multicolumn{2}{|c|}{$\begin{array}{l}\mathrm{c} 2(1)=4.93, \mathrm{p}= \\
0.045^{* *} \wedge\end{array}$} & \multicolumn{2}{|c|}{$\mathrm{c} 2(1)=0.35, \mathrm{p}=0.727^{\wedge}$} & \multicolumn{2}{|c|}{$c 2(1)=0.62, p=0.431$} \\
\hline $\begin{array}{l}\text { Traumatic } \\
\text { Non-traumatic }\end{array}$ & $\begin{array}{l}16 \\
(21.1 \%) \\
5(6.6 \%)\end{array}$ & $\begin{array}{l}33 \\
(43.4 \%) \\
22 \\
(28.9 \%)\end{array}$ & $\begin{array}{l}8 \\
(10.5 \%) \\
0(0.0 \%)\end{array}$ & $\begin{array}{l}41(53.9 \%) \\
27(35.5 \%)\end{array}$ & $\begin{array}{l}7(11.7 \%) \\
3(5.0 \%)\end{array}$ & $\begin{array}{l}30(50.0 \%) \\
20(33.3 \%)\end{array}$ & $\begin{array}{l}17 \\
(22.4 \%) \\
7(9.2 \%)\end{array}$ & $\begin{array}{l}32 \\
(42.1 \%) \\
20 \\
(26.3 \%)\end{array}$ \\
\hline $\begin{array}{l}\text { Comorbidities } \\
\text { No }\end{array}$ & $\begin{array}{l}\mathrm{c} 2(1)=0.0 \\
0.921\end{array}$ & $\mathrm{l} p=$ & $\begin{array}{l}\mathrm{c} 2(1)=0 . \\
0.708\end{array}$ & $p=$ & c2 $(1)=0.9$ & $\mathrm{p}=0.471^{\wedge}$ & $\mathrm{c} 2(1)=0.0$ & $p=0.913$ \\
\hline Yes & $\begin{array}{l}14 \\
(18.4 \%) \\
7(9.2 \%)\end{array}$ & $\begin{array}{l}36 \\
(47.4 \%) \\
19 \\
(25.0 \%)\end{array}$ & $\begin{array}{l}6(7.9 \%) \\
2(2.6 \%)\end{array}$ & $\begin{array}{l}44(57.9 \%) \\
24(31.6 \%)\end{array}$ & $\begin{array}{l}8(13.3 \%) \\
2(3.3 \%)\end{array}$ & $\begin{array}{l}32(53.3 \%) \\
18(30.0 \%)\end{array}$ & $\begin{array}{l}16 \\
(21.1 \%) \\
8(10.5 \%)\end{array}$ & $\begin{array}{l}34 \\
(44.7 \%) \\
18 \\
(23.7 \%)\end{array}$ \\
\hline $\begin{array}{l}\text { Economic Role } \\
\text { within the } \\
\text { Family - pre- }\end{array}$ & $\begin{array}{l}\mathrm{c} 2(1)=28 . \\
<0.001 * * \wedge\end{array}$ & $95, \mathrm{p}$ & $\begin{array}{l}\mathrm{c} 2(1)=28 \\
\mathrm{p}<0.001^{*}\end{array}$ & & NA & & $\begin{array}{l}\mathrm{c} 2(1)=37 \\
\mathrm{p}<0.001 * *\end{array}$ & \\
\hline $\begin{array}{l}\text { LLA } \\
\text { Earner } \\
\text { Dependent }\end{array}$ & $\begin{array}{l}9(11.8 \%) \\
12 \\
(15.8 \%)\end{array}$ & $\begin{array}{l}53 \\
(69.7 \%) \\
2 \\
(2.6 \%)\end{array}$ & $\begin{array}{l}1(1.3 \%) \\
7(9.2 \%)\end{array}$ & $\begin{array}{l}61(80.3 \%) \\
7(9.2 \%)\end{array}$ & & & $\begin{array}{l}10 \\
(13.2 \%) \\
14 \\
(18.4 \%)\end{array}$ & $\begin{array}{l}52 \\
(68.4 \%) \\
0(0 \%)\end{array}$ \\
\hline $\begin{array}{l}\text { Monthly } \\
\text { Income- pre- }\end{array}$ & $\begin{array}{l}\mathrm{c} 2(1)=0.16 \\
1.000^{\wedge}\end{array}$ & $p=$ & $\begin{array}{l}c 2(1)=0 . \\
1.000^{\wedge}\end{array}$ & $17, p=$ & $\mathrm{c} 2(1)=5.0$ & $p=0.167^{\wedge}$ & $\begin{array}{l}\mathrm{c} 2(1)=0.1 \\
1.000^{\wedge}\end{array}$ & $9, p=$ \\
\hline $\begin{array}{l}\text { LLA* } \\
\text { Below Poverty } \\
\text { line } \\
\text { Above poverty } \\
\text { line }\end{array}$ & $\begin{array}{l}0(0.0 \%) \\
8(13.3 \%)\end{array}$ & $\begin{array}{l}1 \\
(1.7 \%) \\
51 \\
(85.0 \%)\end{array}$ & $\begin{array}{l}0(0 \%) \\
1(1.7 \%)\end{array}$ & $\begin{array}{l}1(1.7 \%) \\
58(96.7 \%)\end{array}$ & $\begin{array}{l}1(1.7 \%) \\
9(15.0 \%)\end{array}$ & $\begin{array}{l}0(0.0 \%) \\
50(83.3 \%)\end{array}$ & $\begin{array}{l}0(0.0 \%) \\
9(15.0 \%)\end{array}$ & $\begin{array}{l}1(1.7 \%) \\
50 \\
(83.3 \%)\end{array}$ \\
\hline $\begin{array}{l}\text { Occupational } \\
\text { Status- pre-LLA }\end{array}$ & $\begin{array}{l}\mathrm{c} 2(1)=32 . \\
\mathrm{p}<0.001 * *\end{array}$ & & $\begin{array}{l}\mathrm{c} 2(1)=25 \\
\mathrm{p}<0.001^{*}\end{array}$ & & NA & & $\begin{array}{l}\mathrm{c} 2(1)=32 . \\
\mathrm{p}<0.001 * *\end{array}$ & \\
\hline
\end{tabular}




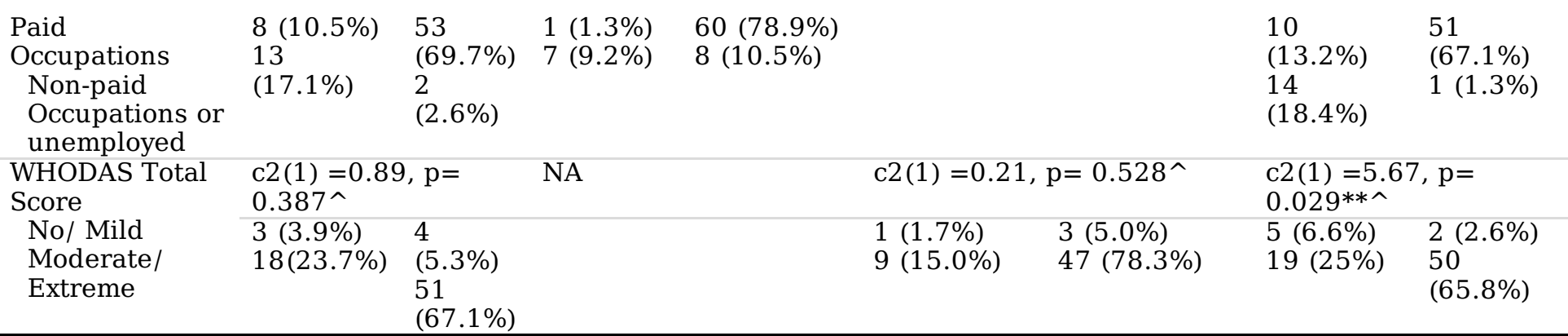

*excludes participants who did not disclose their monthly income $(2.6 \%, \mathrm{n}=2)$ or had no income before LLA $(18.9 \%, \mathrm{n}=14)$

${ }^{* *} \mathrm{p} \leq 0.05 ;{ }^{\wedge}$ denotes where the Fisher's Exact Test $\mathrm{p}$-value was reported given the minimum cell count was less than five

\section{Figures}

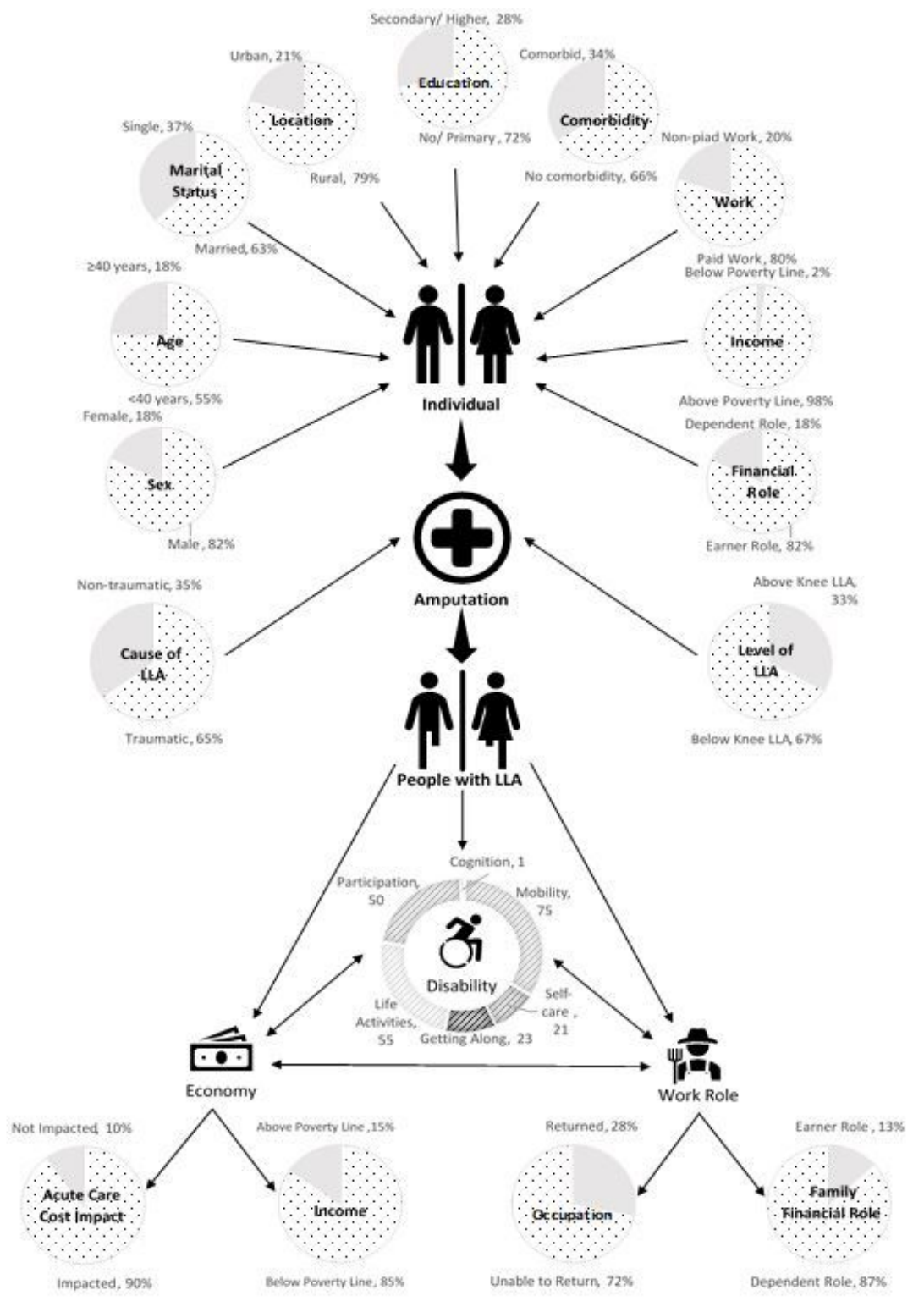

Figure 1 
Diagrammatic summary of results, including characteristics of the participant group pre-LLA, and their disability, economic and work-role status post-LLA and pre-rehabilitation

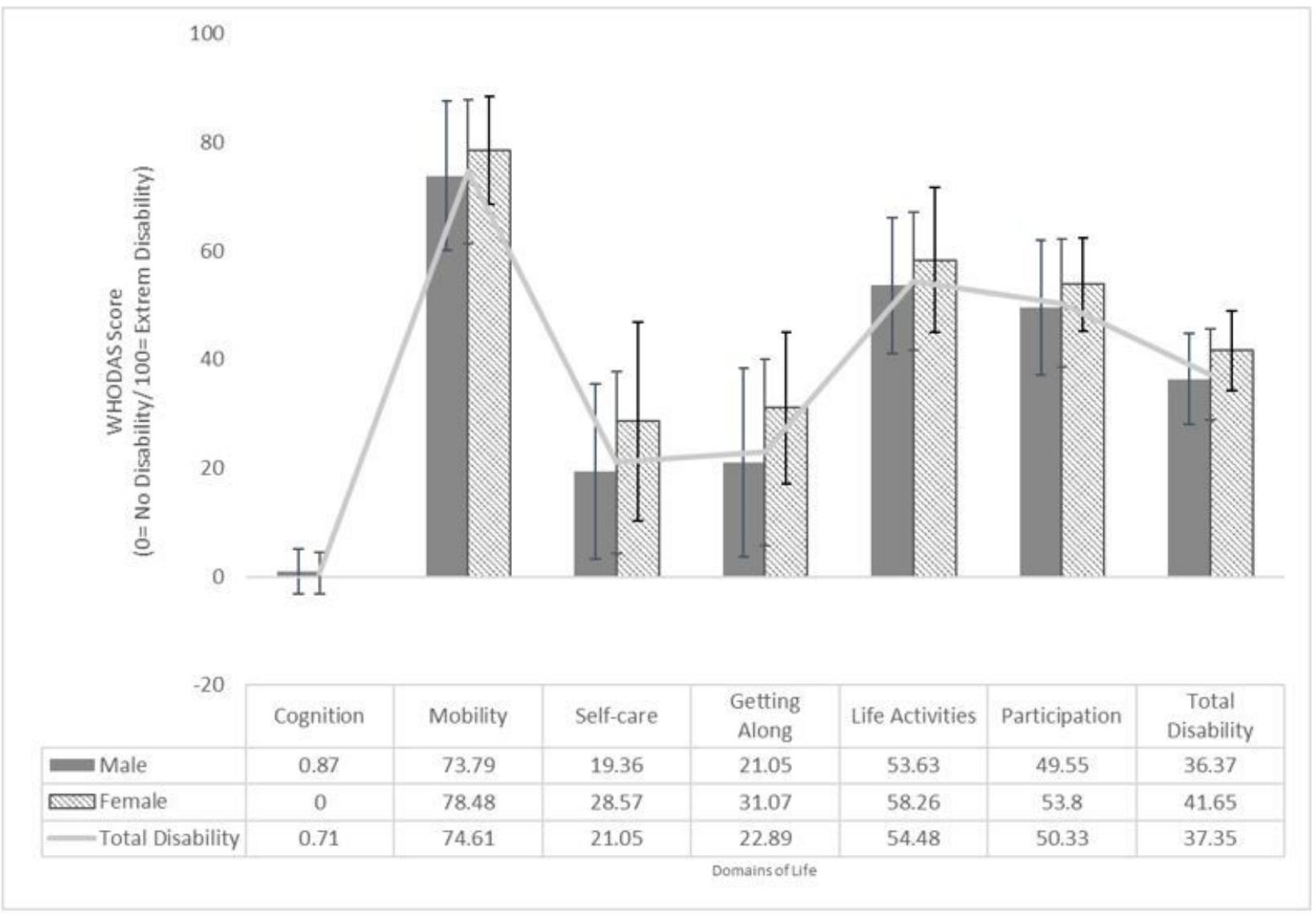

Figure 2

Level of Disability in different dimensions of life (mean and standard deviation) post-LLA and pre-rehabilitation

\section{Supplementary Files}

This is a list of supplementary files associated with this preprint. Click to download.

- Tables13.docx 